\title{
Professional Ethics of Teachers in Educational Institutions
}

\author{
Prakasha G S* and H R Jayamma†
}

\begin{abstract}
This article dwells on the deteriorating value system in India. It presents a glimpse of the value system that existed in India during the Gurukul age, the British reign and also analyzes the present situation. It highlights from various reviews that the education system in India has the potential to nurture the desired value system.
\end{abstract}

Keywords: Professional Ethics, Education, Values, teacher, Moral standards

\section{Introduction}

In this era of modernisation and globalisation, it seems like India has lost its value based society and has been transformed into a materialistic society. It is the result of thinking and behaviour of the human being. Now the crisis is, why this transformation took place and how we can set it back in place. Education is the major agency that can be used to make any changes, hence if only the teacher or management changes their mindset from commercialized ideas to value based thoughts, can we set things right. This can be accomplished by setting examples to others by living a life with values and ethics, for which one should be taught about his profession and its ethics.

Every profession is expected to evolve a set of ethical principles to guide the conduct and behaviours of its members. The ethical principles provide the basis to differentiate between desirable and

\footnotetext{
* Assistant Professor, School of Education, Christ University, Bangalore; prakasha.gs@christuniversity.in

t Reader, P G Dept of Education, Bangalore University, Bangalore
} 
undesirable professional conduct and behaviour. Ethics deals with moral principles, which are usually accepted voluntarily by an individual or a group. The code of professional ethics may be defined as a set of self imposed professional ideals and principles, necessary for the attainment of professional excellence and selfsatisfaction. A code of professional ethics is generally based on two principles, namely, professional integrity and ideals of service to the society.

\section{Need/importance}

Roles and responsibilities of the teacher: Historical Perspective

In ancient India, the teacher enjoyed a very high status and position in the society. The following hymn shows that the teacher was identified with the trinity of Gods for his intellectual and spiritual qualities:

Gurur Brahma gurur Vishnu gurur deva Maheshwarah, Gurur sakshath param Brahma tasmay shri gurve namah (Reference for the hymn)

The teacher is essentially a spiritual being, who receives salutations generally reserved for God and he is the embodiment of the Bliss. During the ancient period, there was no formal written code of conduct in India, especially for the teachers, but their duties and responsibilities are reflected in many ancient texts. The teacher taught the students by precept and by setting personal examplehumility and simplicity were his greatest virtues. Taittiriya Aranyaka states that the teacher must put his heart and soul in the act of teaching. According to the Satpatha Brahmana, the teacher was bound to reveal everything to his pupil who at any rate lived with him. Katha Upanishad lays special stress on the indispensability of the teacher, who was expected to be in possession of essential qualities, viz., profundity of learning, clairvoyant vision and intellectual regeneration. He was regarded as the builder, guide and leader of the society.

After the initiation ceremony, the preceptor treated the pupil like his own son and considered it his sacred duty to impart intellectual and spiritual education of a higher order to his disciples. To 
command his pupils' respect, he put forth before them the ideal of high learning and excellent moral character.

The teachers of medieval India, both in Madrasas and Pathshalas continued to enjoy high social status and commanded respect from his pupils by virtue of their vast knowledge of the religious texts and their noble character. Later on, during the British period, the position of the teacher gradually declined due to the indifferent attitude and defective educational policy of the East India Company and the British Crown towards the education of the Indians. The teacher was considered as a low paid government employee and, therefore, was not provided respectable services and working conditions. A number of thinkers and educationists in modern India have expressed their views concerning the roles and responsibilities of the teacher.

According to Swami Vivekananda, "The only true teacher is he who can immediately come down to the level of the students, and transfer his soul to the student's soul and see through the student's eyes and hear through his ears and understand through his mind. Such a teacher and none else can really teach."

A teacher's work should be guided primarily by love and not by any selfish motive, such as money or name and fame. The teacher should impart man-making and character-building education to his students, through his good conduct and ideal behaviour.

Tagore says, "A teacher can never truly teach unless he is still learning himself. A lamp can never light another lamp unless it continues to burn its own flame. The teacher who has come to an end of his subject, who has no living traffic with his students, can only load their minds; he cannot quicken them."

Mahatma Gandhi, (Young India, 24 January 1925) emphasised that "the teacher himself must possess the virtues that he wants to inculcate in the students. This means that the teacher must practise these virtues himself, otherwise his words will have no effect."

He further highlighted (Young India, April 1929) that "the teacher should be able to establish a heart to heart contact with the students..." The teacher and the students should be in constant 
communication with each other. In fact, the teachers have to fashion the hearts of the students rather than their brains.

About the ethical duties of the teacher, Sri Aurobindo says, "the teacher is not an instructor or task-master; he is a helper and guide. His business is to suggest and not to impose.... He does not impart knowledge to him; he shows him how to acquire knowledge for himself. He does not call forth the knowledge that is within, he only shows him where it lies and how it can be habituated to raise to the surface."

From the above discussion, it is evident that, from ancient India to the present day India, there is a difference in the status and position of the teachers. The author claims that, this is due to the lack of professional ethics in the teaching community and the Educational Institutions. First, let us understand what it is and how we can nurture it.

\section{Concept of Professional Ethics}

Every profession, in order to regulate its terms, conditions, norms and quality of service rendered, has its own professional ethics, which is different from general ethics. In the term professional ethics, the word "ethics" adds to the professional obligation that a profession abides by. Professional ethics is a combination of two words, Professional + Ethics. Here, Professional means an expert, specialized, qualified, proficient, skilled, trained, practiced, certified, proficient, skilled, trained, licensed, mature etc. So, Professional is a term denoting a level of knowledge and skills possessed by an individual or required of an individual to perform an assignment, that is attained through extensive education and training. Secondly, Ethics means principles, morals, beliefs, moral principles, moral values, moral code etc. Indeed the word Ethics is derived from the word Ethos, which means character. In this way, Ethics is a science of character, habits of activity, or behaviour of human beings. It evaluates human habits, character and voluntary determinations and discusses their property or otherwise.

In the words of Mackenzie, "Ethics can be defined as the study of what is right or good in conduct" 


\section{Status of professional ethics as per the reviews}

Over the past few decades, the need for making the teaching profession self-regulatory, by evolving a code of professional ethics for teachers has been articulated from time to time by various commissions and committees on education.

In pursuance of the recommendations of the National Policy on Education (1986, 1992), a Code of Professional Ethics for Teachers was jointly developed by the NCERT and the All India Federation of Primary and Secondary School Teachers' Organizations. The preamble to the code reiterates the resolve of the country's teachers to uphold their professional integrity, strive to enhance the dignity of the profession and to take suitable measures to curb professional misconduct. The professional obligations of a teacher relating to the following, are included in the code: (1) Teacher in relation to the pupils, (2) Teacher in relation to parents and guardians, (3) Teacher in relation to the society and the nation, (4) Teacher in relation to profession, colleagues and professional organizations, and (5) Teacher in relation to the management and administration. Thirty principles related to these areas of a teacher's work serve as guidelines for the teachers' conduct. The primary source of these principles is the spirit of the constitution of our republic. However, the obligations of a teacher enunciated in the scriptures of ancient and medieval times, the views of educational thinkers and the thinkings of various educational commissions and committees have guided the content of the code.

The code highlights that a teacher is not only a purveyor of knowledge for the cognitive development of pupils but is also a democratic and socialising agent, responsible for helping children to gain social and emotional maturity and become useful and selfsupporting citizens. He is expected to teach the students after making a thorough preparation, and refrain from accepting remuneration for coaching or tutoring his own students. He should be just and impartial to all his students irrespective of their caste, creed, sex, status, religion, language and place of birth. He should set a standard of dress, speech and behaviour which should be worthy of example to the students; establish cordial relations with parents and guardians of pupils; cooperate with the head of the institution and with the management to ensure smooth running of 
the institution in accordance with the prescribed norms; avoid making derogatory statements about colleagues, children and their parents; and refrain from taking part in activities which spread feeling of hatred or disaffection among different communities, religious or linguistic groups.

National Policy on Education $(1986,1992)$ had also envisaged that the teacher organizations would also evolve a suitable mechanism for the observance of the code by the teachers. There are reports that the code has been discussed extensively in the meetings, seminars and workshops organized by the teacher organizations and have been formally adopted by them. But suitable mechanism for its observance is yet to be evolved, for which the National Council for Educational Research and Training (NCERT) is providing professional assistance and logistic support to the teacher organizations.

University Grants Commission (UGC) in collaboration with AIFUCTO (All India Federation of University and College Teacher Organization) formed a task force, which has prepared a code of professional ethics for the University and College teachers (UGC, 1989). The report of the task force adopted by the commission has been sent to all the University Vice Chancellors and College Principals for its implementation. The preamble to the code reiterates that the goal of higher education in our country is to produce leaders of society and economy in all areas of manifold activities, with a commitment to the ideals of patriotism, democracy, secularism, socialism, and peace. Higher education should strive for academic excellence and progress of arts and science. In view of this, rights and responsibilities of teachers are indicated in the code. The professional obligations of a teacher in higher education institutions are enlisted in seven parts-(i) Teachers and their responsibilities; (ii) Teachers and the Students; (iii) Teachers and colleagues; (iv) Teachers and authorities; (v) Teachers and non-teaching staff; (vi) Teachers and guardians; and (vii) Teachers and Society. Thirty-eight ideals related to these areas of a teacher's work serve as guidelines for a teacher's professional behaviour.

However the studies related to professional ethics such as Saran, S.A. (1975), Mishra, G. (1977), Jaleel, S.S. and Pillay, G.S. (1979), 
Wadhawan, C.L.(1980), Rana, A. U. (1981), Aruldoss, J. (1981), Mathur, V.R. (1981), Jain, B (1982), Garg, N. K. (1983), Sengupta, Parijat. (1990), Joshi, Rajni (1991), Tapodhan, H.N. (1991), Bisaria s. (1991,ERIC), Mohan Raju, P (1992), Ratnappa, C. (1998), Pandey, Manju and Maikhuri, Rama (1999), and N. S. Mumthas (2006) had revealed various causes for not following the professional ethics, such as mobility, caste, age, inefficient Principals, locality from where the teacher comes, and bureaucratism. This calls out for an assessment of professional ethics prevailing in the country and to take measures to its adherence.

\section{Educational Implications}

- If the teacher bears good professional ethics in relation to his profession, the ethics are automatically transformed to the coming generations.

- The deteriorating status of the profession will gain back its potential status.

- An effective use of the professional ethics has the power to stop the so called "terrorism" in the world.

- Professional ethics will help in the spread of peace and international understanding across the Globe.

- Professional ethics will fight against "Corruption" and lead to a Hygienic life.

\section{Conclusion}

I believe that a day will come soon, when all the people will have sophisticated modern gadgets, western lifestyle and materialistic attitudes, but would die for any sign of values in family and society at large. Instead, come lets join hands and sow the seeds of moral ethics right now or else we will remain blind folded till the end.

\section{Reference}

Aloni, N. (2006). The fundamental commitments of educators. Ethics and Education, 3(2), 149-159. 
Arora, G. L. \& Chopra, R.K. (2004). Professional ethics for teachers, in J. S. Rajput (Ed), Encyclopaedia of Indian Education (Vols L-Z). New Delhi: NCERT.

Aruldoss, J. (1981). Professional ethics of college teachers. M.Phil. MKU. Third survey of Research in Education, 1978-1983, M. B. Buch, NCERT

Loombha, K., \& Loombha, P. (2007). Miracle of Teaching. Professional Ethics, 7, pp129-131.

Sengupta, P. (1990). Professionalization of teachers: A case study of men and women teachers of Calcutta University. Ph.D., Edu. Jawaharlal Nehru Univ. Fifth survey of Educational Research, 1988-1992, Volume-1, Teacher education pre-service and In-service J.N. Joshi, NCERT. 